\title{
A digitális korszak beköszönte és a Covid-19-világjárvány generálta helyzetben történő helytállás
}

\section{RUZSONYI Péter ${ }^{1 \oplus}$}

\begin{abstract}
A tanulmány részletesen ismerteti a Rendészettudományi Kar (Kar) szervezetének a bővitését, a Katasztrófavédelmi Intézet és a Nemzetbiztonsági Intézethez tartozó Polgári Nemzetbiztonsági Tanszék és Terrorelhárítási Tanszék Kar szervezetébe integrálódását, valamint új szakirányok létrehozását. A Ludovíceum tantárgycsoport bevezetése és a kettős jogállású hallgatók nappali munkarendü képzésének elindítása fontos állomásnak volt tekinthető a Kar életében. Jelentős mérföldkő volt a távoktatás, a digitális oktatás bevezetése, a digitalizáció és a képzések megreformálásának folyamatában elindított Kreativ Tanulás Program.
\end{abstract}

Kulcsszavak: Ludovíceum, kettős jogállás, digitalizáció, kreatív tanulás, koronavírus-járvány

\section{Elözmények - szembenézés egy új generáció tanulási/tanítási elvárásaival}

Hallgatóink ma már valamennyien a Z generáció (1995-2009 között születettek) tagjai, akik beleszülettek a digitális technológiák világába. Számukra már elképzelhetetlen az élet a Web 2.0, a mobiltelefonok és más digitális, valamint kommunikációs eszközök rendszeres használata nélkül. Úgy is fogalmazhatunk, hogy ők „digitális bennszülöttek", akiknek a tanulási szokásaik a korábbiaktól teljesen eltérőek. Oktatóként számtalan esetben szembesültünk azzal, hogy ez a különbség kivédhetetlenül feszültséget generál az oktatási rendszeren belül - elsősorban a tanítási módszerek területén. Dékáni időszakom elején többször beszéltünk ennek a problémának a megoldási lehetőségeiről; leginkább az Egyetem által kifejleszteni tervezett Kreatív Tanulás Program bevezetésétől reméltünk jelentős eredményeket. Tisztában voltunk azzal, hogy oktatóként valamennyiünknek új didaktikai eljárásokat kell megtanulnunk, mert a régi „klasszikus” módszerek alkalmazása már nem célravezető. Elfogadtuk,

\footnotetext{
Dr. habil. Ruzsonyi Péter, bv. dandártábornok, Nemzeti Közszolgálati Egyetem Rendészettudományi Kar, Büntetés-végrehajtási Tanszék, dékán, tanszékvezető egyetemi tanár.

Péter Ruzsonyi, PhD, habil, Corr. Brigadier-General, University of Public Service, Faculty of Law Enforcement, Department of Corrections, University Professor, Dean, Head of Department.

E-mail: ruzsonyi.peter@uni-nke.hu
} 
hogy hallgatóink hozzá vannak szokva a gyors információáramláshoz és annak befogadásához, hogy képesek egyszerre több mindennel párhuzamosan is foglalkozni, ugyanakkor a felvett információk csak részlegesen rögzülnek bennük, és nem képesek sokáig egy dologra koncentrálni. Terveztük a változtatást, vizsgáltuk a lehetőségeket, de nem is sejtettük, hogy a sors milyen hamar és mennyire drasztikusan kényszerít ki mindnyájunkat a digitális térbe.

\section{A Kar szervezeti átalakítása a képzésfejlesztés érdekében}

A Rendészettudományi Kar 2018 és 2021 között jelentős mértékben bővült. A korábban karközi intézetként múködő Katasztrófavédelmi Intézet (KVI) és a Nemzetbiztonsági Intézetből (NBI) a Polgári Nemzetbiztonsági Tanszék, valamint a Terrorelhárítási Tanszék Karunk szervezetébe integrálódott. A vizsgált időszak másik jellemzője volt több szervezeti egység részleges módosulása. A korábban meglévő mindhárom oktatási intézet (Kriminalisztikai Intézet, Rendészeti Magatartástudományi Intézet, Alkotmányjogi és Rendészeti Jogi Intézet) megszűnt, az őket alkotó tanszékek egy része önálló szervezeti egységként folytatta a munkáját. Volt olyan tanszék, amelynek az összetétele és feladata is módosult (a Kiberbünözés Elleni Tanszék beolvadt a Bűnügyi, Gazdaságvédelmi és Kiberbűnözés Elleni Tanszékbe), sőt olyanok is, amelyek megszűntek (Közjogi és Rendészeti Jogi Tanszék és a Nemzetközi és Európai Rendészeti Tanszék). Ugyanakkor új tanszékként jött létre az Igazgatásrendészeti és Nemzetközi Rendészeti Tanszék.

\section{Oktatás- és képzésfejlesztés}

$\mathrm{Az}$ elemzett időszakban az oktatásfejlesztési és -szervezési tevékenység területén számos változás következett be. Sor került a polgári nemzetbiztonsági mesterszak, a biztonsági szervező mesterszak, valamint a szervezett bünözés elleni küzdelem elmélete és gyakorlata szakirányú továbbképzési szak indítására. A képzésfejlesztés egyik legfontosabb eleme a rendvédelmi szervező szakirányú továbbképzési szak indítása volt, mivel e képzéssel egyfelól az RTK hatáskörébe került valamennyi tiszti kinevezést megalapozó képzés, másfelől ezt a továbbképzési szakot az egyes rendvédelmi szervek együttmúködésével alakították ki és indították el.

Az államtudományi képzési területen szerezhető képesítések jegyzékéről és a képzések képzési és kimeneti követelményeiről szóló 222/2019. (IX. 25.) számú kormányrendeletben megjelent új KKK alapján a bünügyi és rendészeti alapképzési szakok, illetve a bűnügyi igazgatási és rendészeti igazgatási szakok, a katasztrófavédelmi alapszak és polgári nemzetbiztonsági alapképzési szak, valamint a rendészeti vezető, a kriminalisztika, a katasztrófavédelem és a polgári nemzetbiztonsági mesterképzési szakok ajánlott tantervének átdolgozása megtörtént. 
A ciklikus óratervezésre, a 14 hetes szorgalmi időszakra, valamint a hallgatói kontaktórák számában a heti 30 órára történő átállás, illetve a Ludovíceum tantárgycsoport tantervbe történő beépítése miatt a tantervmódosítás jelentős óraszámcsökkenéssel járt és egyes tantárgyaknak a tantervből történő törlését okozta. A hallgatók ismereteinek minél szélesebb körű bővítése érdekében új szabadon választható tantárgyak bevezetésére is sor került.

A 2020-as felvételi eljárásban több évtized óta először, az ORFK-val együttmüködve, a Kar felvételt hirdetett a bűnügyi igazgatási alapszak bünügyi nyomozó szakirány, valamint rendészeti igazgatási alapszak közrendvédelmi szakirány nappali munkarendú, hároméves képzéseire. A pályázatra azok jelentkezhettek, akik a rendőrség hivatásos tiszthelyettes- vagy zászlósi állományába tartoztak. Ezzel a lépéssel - több évtizednyi kihagyás után - ismételten megjelentek a rendőrség állományából is a kettős jogállású hallgatók Karunk nappali munkarendes képzésében.

$\mathrm{Az}$ alapképzésen új képzésként indult nappali munkarendben a négyéves bűnügyi alapszakon a kibernyomozó, levelező munkarendben a hároméves bủnügyi igazgatási alapképzésen az informatikai nyomozó szakirány, illetve az Oktatási Hivatal bejegyezte a bevándorlási szakirányt, amelynek legfontosabb célja rendőrtisztek képzése az Országos Idegenrendészeti Főigazgatóság számára.

\section{Covid-19-világjárvány oktatási és oktatásszervezési kihívásai}

Jelen dékáni időszakom legkarakteresebb jellemzője, hogy az érintett három évnek több mint a fele a Covid-19-világjárvány árnyékában telt el. Egyetemünk hamar képes volt dinamikusan reagálni a kihívásokra; az oktatás biztosítása mellett a járvány terjedésének megelőzése és az egészségvédelem került a mindennapi tevékenységünk fókuszába. Az Egyetemen létrehozott Járványügyi Operatív Törzs (JOT) tagjaként mindvégig tevőlegesen részt tudtam vállalni az oktatás folyamatos biztosítása és a rendkívüli helyzetből következő speciális szabályozók elkészítésében, valamint az atipikus lebonyolítású vizsgarendszer és felvételi eljárás rendjének kidolgozásában.

A Kormány által a veszélyhelyzet kihirdetéséről szóló 40/2020. (III. 11.) Korm. rendeletben, majd a 478/2020. (XI. 3.) Korm. rendeletben foglaltak alapján foganatosított intézkedések fokozottan érintették Egyetemünk működését. A járvány első hullámának tetőzésekor - 2020 tavaszától - a tisztjelölt, a kettős jogállású, valamint a migrációs szakirányú hallgatók speciális rendészeti feladatok ellátásában vettek részt. A rendőrtisztjelölt hallgatók a nyugati határon kapcsolódtak be a határforgalom ellenőrzésébe, a büntetés-végrehajtási hallgatók börtönökben végeztek munkát, a migrációs szakirányú hallgatók pedig az Országos Idegenrendészeti Főigazgatóság szervezeténél dolgoztak. A visszajelzések a rendvédelmi szervek vezetői és a hallgatók részéről egyöntetűen rendkívül pozitívak voltak. A speciális feladatok ellátásában részt vevő tisztjelöltjeink életükben először tapasztalták meg, hogy mit jelent éles helyzetben a rendészeti munka. 
Az érintett hallgatókra ugyanakkor - hónapokon keresztül - dupla feladat hárult: ez alatt az időszak alatt a speciális rendészeti feladatok ellátása mellett párhuzamosan a tanulmányi és vizsgakötelezettségeiknek is eleget kellett tenniük. Ennek biztosítása érdekében az NKE azonnal fejleszteni kezdte az informatikai rendszerét, új platformokat alakított ki, illetve tett elérhetővé. Rövid időn belül biztosítottá vált, hogy hallgatóink távoktatás útján hozzájussanak a szükséges elméleti ismeretekhez, a vizsgák során pedig online módon tettek tanúbizonyságot elméleti felkészültségükről.

A járványhelyzetből adódó feladatok ellátásából oktatóink is kivették a részüket. Országos rendőrfőkapitány úr - belügyminiszter úr felhatalmazása alapján, a járványügyi veszélyhelyzetre való tekintettel - a Rendőrségtől a Karra vezényelt hivatásos állomány részére 2020. április 6-tól augusztus 20-ig speciális rendészeti feladatok ellátását rendelte el, amelynek értelmében a Karunkról 28 oktató váltásos rendszerben látott el szolgálatot az ORFK-n.

A rendvédelmi szervek vezetői elismeréssel nyilatkoztak mind a tisztjelöltek, mind az oktatók által végrehajtott feladatok magas szintű szakmai színvonaláról. A feladatokba bevont személyek a veszélyhelyzet során tanúsított hozzáállásukkal, példamutatásukkal és elvégzett tevékenységükkel nagymértékben hozzájárultak Karunk szakmai elismerésének növeléséhez.

\section{Tudományos és nemzetközi élet}

Jelen fejezetben a rendészettudományi kari tudományos és nemzetközi aktivitással, illetőleg az Erasmus+ mobilitási programmal foglalkozom részletesen.

\section{Tudományos aktivitás}

Az elemzett időszakban Karunk tudományos életének talán legmeghatározóbb mozgatórugója a KÖFOP-2.1.2.-VEKOP-15-2016-00001 „A jó kormányzást megalapozó közszolgálat-fejlesztés" program volt, amely a pénzügyi és az adminisztratív háttér biztosításával tette lehetővé nyolc kutatócsoport és hat kiemelt kutatóműhely létrehozását, valamint két doktori, hét posztdoktori, két habilitációs és két professzori program megindítását.

Hagyományteremtő és identitást növelő céllal Kari Napot választottunk, amelyen a hivatásunkhoz és a tudományhoz kapcsolódó előadásokkal demonstráltuk a rendészettudomány dinamikus fejlődését.

Az elmúlt évek során folyamatosan dinamizáltuk a Karon belüli tudományos tevékenységet. Nagyon fontosnak tartjuk, hogy valódi és élő tartalommal töltsük meg azt a középtávú vezetői elvárást, amely Egyetemünket valóban a legkiválóbbak közé emelheti. Ennek kiteljesítése érdekében nélkülözhetetlennek tartjuk a Karon belüli 
szakmai és tudományos munka hatékonyságának további növelését. Törekvéseink helyességét igazolja, hogy a 2019. évben egyetemi tanári kinevezések, habilitált doktori címek odaítélésére és $\mathrm{PhD}$-fokozatok elnyerésére is sor került.

A Karon létrejött Kriminálpszichológiai Kutatóműhely jelentős eredményekkel növeli az Egyetem elismertségét, és jó úton halad azon célja felé, hogy a honi kriminálpszichológia első számú tudományos közösségévé váljon.

Általánosságban is megállapítható, hogy kutatásaink fő irányaként olyan eredményeket igyekszünk felmutatni, amelyek hatékonyan támogatják az egyes rendvédelmi szervek munkáját, ugyanakkor az egész magyar tudományos élet tekintetében hozzáadott értéket jelenítenek meg.

A Karon a hallgatói tehetséggondozás centruma a Szent György Szakkollégium és a Katasztrófavédelmi Szakkollégium.

\section{Nemzetközi aktivitás}

Az elmúlt három évben a nemzetközi szerepvállalásunk - a Covid-19 miatt - egyenetlen volt. Az első másfél évben jelentős fejlődést értünk el, azonban a második időszakban a megtorpanás törvényszerű és elkerülhetetlen volt.

Karunk a 2018-as évben fogadott először külföldi vendégoktatót az International Chair Program keretében, Rebecca Hayest, a University of Michigan docensét. Rebecca Hayes órákat adott az alap- és mesterképzésben, a doktori képzésben és vezetett egy kurzust az Erasmus-program keretében is.

2019-ben az oktatóink közül összesen 32 fő 55 külföldi kiküldetést teljesített a következő 15 országban: Brazília, Csehország, Egyesült Királyság, Franciaország, Hollandia, Horvátország, Kanada, Kína, Németország, Olaszország, Oroszország, Portugália, Románia, Szerbia, Törökország. Ugyanebben az évben 135 főt fogadtunk kilenc országból (Németország, Hollandia, Lengyelország, Törökország, USA, Kína, Fülöp-szigetek, Vietnám, Franciaország). Németországból 81 fő látogatott el az RTK-ra szakmai gyakorlat, illetve az egyetem megismerése céljából, valamint szakmai előadásokra.

A Kar sikeresen működött közre több nemzetközi rendészeti szervezet munkájában, így a CEPOL, a Frontex, de különösen az AEPC (Rendőrtiszti Akadémiák Európai Szövetsége) tevékenységében. Ez utóbbi esetében például - a magyar rendészeti felsőoktatás 50. évfordulójára is tekintettel - elnyerte a 2021. évi konferencia és tanácsülés megrendezésének jogát.

Megtorpanás (2020): A Covid-19-járvány kitörése nem kedvezett a nemzetközi kapcsolatoknak, hiszen a tervezett külföldi kiutazások és vendégfogadások nem valósulhattak meg, mindenfajta kommunikáció a nemzetközi partnerekkel az online térbe szorult. 


\section{Erasmus+ mobilitási program}

Jelenleg 15 ország 27 egyetemével van Erasmus-kapcsolatunk. A külföldi hallgatók számára öt modulban 33 angol nyelvü képzést tudunk kiajánlani.

Megítélésem szerint Karunk munkatársai és hallgatói egyre aktívabban élnek az Erasmus+ mobilitási program adta lehetőségekkel. A 2018-2020 közötti időszakban az oktatói mobilitás keretében munkatársaink 24 alkalommal tanítottak külföldön, és 14 oktatót fogadtunk európai partneregyetemekről.

A vizsgált időszakban hallgatóink az Erasmus+ hallgatói mobilitás keretében 50-en utaztak külföldre tanulni, valamint 68 külföldi diák érkezett hozzánk egy-egy szemeszterre.

Az Erasmus-aktivitás fokozatosan emelkedő tendenciája 2020-ban torpant meg. A Covid-19-világjárvány miatt a 2020-as évben 19 fő hallgató érkezett a Karra, azonban ők a távoktatás elrendelése után hazatértek és online formában fejezték be a képzést, illetve 11 fő diákunk volt külföldön (egy részük hazautazott a járvány kitörése után). A 2020/21-es tanév I. félévében a Karra nem érkezett a külföldi partnerintézményekből Erasmus+ tanulmányi mobilitás keretében hallgató, és az akkor hatályos rektori utasítás alapján RTK-s hallgató sem vett részt külföldi mobilitásban. Az oktatói és munkatársi mobilitás keretében a 2020-as évben mindössze egy fő érkezett Karunkra, illetve egy fő kari oktató volt külföldön.

\section{Rendészettudományi Doktori Iskola (RDI)}

A rendészettudományi felsőoktatás egyedülálló helyet foglal el a rendészettudományi kutatás, oktatás, fejlesztés és nevelés területén. A Rendészettudományi Doktori Iskola (RDI) rendészettel kapcsolatos tudományos tevékenységének célja a nemzeti közszolgálat minőségének javítása, a folyamatos megújítás lehetővé tétele, illetve törekvés az innovatív és nemzetközileg is elismert tudásközponttá és fejlesztőmühellyé válásra.

Az egyetemi struktúrában 2019-ben bekövetkezett változás miatt a korábban az Egyetem közvetlen alárendeltségében múködő doktori iskolák tudományáganként, a Magyar Felsőoktatási Akkreditációs Bizottság által akkreditált önálló szervezeti egységként, de az egyetem egyes karaihoz rendelve múködnek tovább. A Rendészettudományi Doktori Iskola a fentiek értelmében ma már a Rendészettudományi Kar részét képezi. Ebből a változásból következően megszúnt a Rendészettudományi Doktori Iskola Tanácsa, helyét a doktori iskola legfóbb döntéshozó szerveként múködő Tudományági Doktori Tanácsa vette át, amelyet a doktori iskola törzstagjai, választott külső tagjai és a tanácskozási jogú tagjai alkotnak. A doktori iskola törzstagjainak száma 13 fő. A doktori iskolában jelenleg több mint 80 oktató lát el feladatot, amelyből 53 fő témát is hirdet. 
Rendkívül örömteli eseménynek tartjuk, hogy 2021-ben az RDI-ben végre megtörténtek az első műhelyviták, sőt az első PhDfokozat-szerzések is.

\section{Összegzés}

A 2018-as dékáni székfoglaló beszédemben több, számomra nagyon fontos alaptételt és célkitűzést fogalmaztam meg. Mindenekelőtt - szemléleti alapelvként - a hallgatóközpontúságot kívántam a Kar tevékenységi rendszere jellemzőjeként megőrizni. Ennek érdekében egy folyamatosan megújuló és magas színvonalú oktatói kar és képzési stratégia kialakítását, a hallgatói elit döntés-előkészítésbe és a végrehajtásba történő bevonását, valamint egy stabil támogató és együttmúködő környezet együttes megteremtését tartottam az egyik legfontosabb feladatomnak. Hangsúlyoztam ugyanakkor, hogy ez a folyamat kizárólag az oktatási intézményben együtt tevékenykedő oktatók, tudós egyéniségek, ismeretet átadó előadók, személyes életpéldával is ható nevelők emberi kvalitásainak segítségével teljesedhet ki. Úgy gondolom, hogy a kitûzött célok jelentős részét sikerült megvalósítanunk. Köszönet ezért mindazon vezetőknek, munkatársaknak és hallgatóknak, akik átsegítették a Kart a felmerült nehézségeken és segítő közreműködésükkel hozzájárultak az elmúlt három év sikereihez.

\section{ABSTRACT \\ Entering the Digital Era and Coping with the Situation Caused by the Covid-19 Pandemic}

Péter RUZSONYI

This study provides a detailed description of the organisational growth of the Faculty, the integration of the Institute of Disaster Management, and of the Department of Civilian National Security and the Department of Counter-Terrorism, both belonging to the Institute of National Security, as well as the creation of new specialisations. The introduction of the Ludoviceum subject group and the launch of full-time training of students with dual legal status are seen as important turning points in the life of the Faculty. The introduction of distance learning and digital education, and the launch of the Creative Learning Programme as part of the process of digitalisation and training reform also mark significant milestones.

Keywords: Ludoviceum, dual legal status, digitalisation, creative learning, coronavirus pandemic 